\title{
Corporate Social Responsibility and Consumer Behavior: A Study from Pakistan
}

\author{
*Adnan Safi ${ }^{1}$, Muhammad Ismail Ramay² \\ ${ }^{1}$ Federal Urdu University of art science and technology, Islamabad, Pakistan \\ ${ }^{2} \mathrm{Al}$ Khair University, Pakistan \\ *adnansafii@gmail.com
}

\begin{abstract}
Pakistani consumers must be well informed that, in achieving their corporate goals, organizations now bear greater responsibility to develop healthy environment and aware society. This study aims towards assessment of the impact of Corporate Social Responsibility on Consumer Behavior in Pakistan and to analyze whether consumers reckon Organization's CSR initiative before buying decisions of goods and services. Carroll definition of CSR was adopted here that addresses whole range of economic, legal, ethical and philanthropic responsibilities. A Survey Questionnaire in this regard was carried out and 313 responses were collected across the different corners of Pakistan that further lead to culmination of this analysis report. The analysis showed that there is significant positive correlation between all CSR components and consumer behavior. However, Pakistani consumer's priority appeared to be different than offered by Carroll's Classical Pyramid, where economic responsibility was considered to be the greatest priority, followed by philanthropic, legal \& ethical responsibilities.
\end{abstract}

\section{Keywords: Carroll's Pyramid, Corporate Social Responsibility, Consumer Behavior, Pakistan}

\section{Introduction}

The concept of Corporate Social responsibility (CSR), in Pakistan, has become an important issue among the Business Community during recent years. Flack and Heblich (2007) argue that, the word CSR was first used in 1953 by Bowen when he published the Seminal Book Known as "Social Responsibility of the Businessman". After span of a decade, many authors like Davis (1960), Frederick (1960) and Walton (1967) brought the Concept of Corporate Social Responsibility into further course of debate (Flack \& Heblich, 2007). Since then CSR has become an important subject of debate and empiricism among Researchers and Practitioners (Rahim, Jalaludin, \& Tajuddin, 2011). The main motif of CSR is that organizations are confined to work for social betterment. According to Carroll (1991) organizations does not only carry the economic responsibility of making profit and legal responsibility to obey the rules and regulations of the country but they also have an ethical responsibility i.e. to follow the cultural norms and values. CSR is now viewed as a strategic tool to achieve economic objective of the organization and create wealth (Garriga \& Melé, 2004). Carroll (1991) divided CSR in four categories and made a pyramid of the Economic, Legal, Ethical and Philanthropic responsibilities.

- The first item in Carroll's Pyramid is Economic Responsibility. It deals with the profit making of the organization.

- Legal Responsibility comes next and in refers to rules and regulations adopted during the process.

- Then comes the Ethical Responsibility that directs that an organization should follow the norms and values of the society along with laws.

- Philanthropic Responsibility covers the volunteer / charity work, contributing something to the society (donations, benevolence, voluntary work etc.).

In developed countries, research work has been conducted on frequent basis to find out the relation between organization behaviors and consumer purchase intentions. Unfortunately, in Pakistan we don't have such consecrated studies in this particular field as CSR is still in its initial stages and only few companies conduct CSR, where most are multinational having their own CSR standards and policies. The worthy findings forwarded by Lafferty, Barbara and Ronald (1999) shows that advantageous repute of a company is cordially associated with the purchase intentions of a client and help him to distinguish between the different companies in market and their products or services. According to Brown \& Dacin (1997) customer's loyalty and commitment will grew stronger if organizations act sensibly and responsibly in terms of their environmental and social responsibilities. According to assessment of Ali, 
Rehman, Yilmaz, Nazir and Ali (2010), there is a relation between Corporate Social Responsibility and consumer behavior.A little research has been done on CSR and consumer behavior in Pakistan and it showed that CSR, in Pakistan, is viewed as corporate philanthropy and often being used synonymously, there is also a mindset that considers CSR "a simple compliance with law". Because of better education and potent influence of the media; consumers, now a days, are more aware of Corporate Social Responsibility. Organization without CSR is no longer accepted and now organization itself can't underrate the importance of CSR. The aim of the business is no longer just to make wealth but to act responsibly towards the stakeholders. Well managed organizations are concentrating on actions that can be beneficial for stakeholders as well will earn more profit. (Harrison \& Freeman, 1999).This paper intends to examine the relationship between Corporate Social Responsibility and consumer behavior in Pakistan. We are provoked to evaluate whether a Pakistani consumer considers the initiatives based on CSR before purchasing a product or he still relies on old conventional orders? Keeping in mind Carroll's Pyramid of CSR, we'll find what element has cast more influence on a Pakistani consumer? In addition, the purpose of this research is to determine the general awareness of Pakistani Consumers towards Corporate Social Responsibility. The findings of this research will serve corporations to understand consumer priorities for CSR activities and organization can build a strategy to increase its sales. The study will also contribute to the existing literature.

\section{Literature Review}

According to Carroll (1979), Corporate Social Responsibility is a tool that "encompasses the economic, legal, ethical, and discretionary expectations that society has from the organizations at a given point in time". Carroll (1979) argued that these responsibilities not only serve beneficial for the sake of organization but for the society as well. It creates a social contract between organization and stakeholders that compels the organizations to consider social interest while making decisions (Andreasen \& Drumwright, 2001). According to Carroll (1991) Economic, Legal, Ethical and Philanthropic responsibilities are the major elements of Corporate Social Responsibilities, also known as the Carroll's CSR Pyramid. Carroll's Pyramid of CSR is one of the most quoted definitions in the literature (Dusuki, 2005). As a conceptual model, this four-element model provides extensive support to the business organizations in understanding CSR philosophy and offers a useful roadmap for beginners to engage in CSR activities (Belal, 2008). Economic and legal responsibilities are very important as far as an organization's interest is concerned; ethical responsibilities are expected by the society while philanthropic responsibilities are socially desired (Windsor, 2001). Black (2001) conducted a study in Australia and presented Australian model of Corporate Social Responsibility (CSR), where economic responsibility was preferred the most, after that legal, philanthropic and ethical responsibility came categorically. A survey conducted by Rahim, Jalaludin \& Tajuddin (2011) in Malaysia, economic responsibility was still the utmost priority followed by philanthropic, legal and ethical responsibilities. Saleh (2009) argues that investors perceive corporations as responsible corporate citizens if CSR activities are being performed. Society accepts corporation's aim to maximize the revenue to the extent that they kept in view the social development and environmental stability.

Economic responsibilities: According to Carroll (1979) Economic responsibility is the fundamental unit of organization. Rahim, Jalaludin \& Tajuddin (2011) argues that the economy of organization is affected by the methods through which the organization relates to its stakeholders i.e. community, employees, suppliers, shareholders, competitors and also the natural environment. Economic Responsibility does not only destined maximize the shareholders' interest but also stakeholders' interest too. In US, a research was conducted by Maignan and Ferrell (2004) they find out that it could be dangerous if the economic achievements are not good and the organization claim to socially responsible. Maignan and Ferrell (2004) pointed out the experience of Ben Jerry Inc., Ice cream producer who were often alleged of ignoring the economic performance due to its numerous philanthropic activities.

H1: Economic responsibility is associated with consumer behavior.

Legal responsibilities: In order to achieve the economic responsibilities, organizations need to work within the rules and regulations to achieve the "social contract" between organization and society (Masaka, 2008).Economic and Legal responsibilities are co-related and they reflect the expectations of society about organizations to achieve their economic goal within the frame of legal requirements (Goddard, 2005). Legal responsibilities are that organizations embrace the expectation of the society to achieve their goals within the law (Dusuki, 2005). Corporation is intended to maximize their profit within 
the boundaries of law, which clarifies what are prescribed fair processes. The belief of society is that goods and services and the relation with shareholders will meet at least minimal legal criteria. In developed countries, legal responsibilities normally have a higher priority as compare to developing countries. In later, although there is less pressure for good conduct still it does not means that organizations should violate the law. That's only because the legal infrastructure is poorly developed in the developing countries (Belal, 2008). It is also important for corporations to comply with other legal obligation such as employee welfare, consumer protections laws, pollution control and tax payment. Numerous research analysts argue that the most suitable example of irresponsible behavior in developing countries is tax avoidance by companies, opposing their CSR claim of good conduct (Christensen \& Murphy, 2004).

H1: Legal Responsibilities have impact on consumer behavior

Ethical Responsibilities: Though economic and legal responsibilities signify moral values regarding justice and fairness; ethical responsibilities are those actions or practices which are not covered earlier and are beyond the limitations of legal responsibilities but expected or prohibited by the society (Carroll 1979). Ethical responsibility goes beyond the limits of law by developing an ethics ethos that businesses can live in(Solomon, 1994).According to a survey conducted by Creyer and Ross (1997) on parents of elementary school students to measure ethical behavior of organizations found that the parents expects organization to do their business ethically. Several respondents were ready to pay extra money for products of ethical organization. Crane and Matten (2010) argues that ethical responsibility shares a higher priority in Europe than in the Developing countries. Whereas ethical responsibility seems to have less impact on the CSR agenda in developing countries (Belal, 2008).

H1: Ethical responsibilities is related to consumer behavior

Philanthropic responsibilities: Carroll (1991) argues that it is vital for all the employees (managers and workers) to contribute in charitable and volunteer activities in their native communities, particularly in schemes that improve the quality of the lifestyle in a society. Philanthropic responsibilities unlike ethical responsibilities are not expected in a moral or ethical sense. Philanthropic responsibilities are the voluntary and optional aspect of Corporate Social Responsibility and not at any cost related to ethical culture or profit of the organization (Ferrell, 2004). Philanthropic responsibilities tend to depict an advertising CSR manifestation in developing countries (Ahmad, 2006; Amaeshi et al., 2006; Arora and Puranik, 2004). Society wants organizations to provide their money, services and time to their employee for contribution in charitable purposes or programs. Organizations are not considered immoral if they do not attain their philanthropic goals. Though, on organizational level it is volunteer job but society wants the organization to be philanthropically responsible for discharging their charitable services in the best interest of society (Carroll, 1991). Fombrun, Gardberg and Barnett (2000) states that though, philanthropic responsibilities may not produce direct financial returns but it will provide an organization with competitive advantages in long term through intangible gains in image, legality or loyalty of employees.

H1: Philanthropic responsibilities have impact on consumer behavior.

Stakeholder Theory: A strong argument for organization to adopt CSR comes from stakeholder theory. Stakeholder theory identifies the need to be responsive to the demands on memberships of the public who will be affected by (i.e. have a "stake" in) the corporation's actions. Freeman (1984) defined stakeholders as "Any group or individual who can affect or is affected by the achievement of the firm's objectives". The main stakeholders of an organization are the shareholders, consumers, public entities and workers of the organization. The stakeholder theory is projected to extend the organization's idea of its rules and responsibilities outside the functions of profit maximization to involve benefits and rights of non-stockholding groups (Mitchell et al., 1997). According to this concept, anybody by whom the business objective if affected and who might be affected by its recognition is a stakeholder (Roberts, 1992).

Consumer Behavior towards Corporate Social Responsibility: Many research analysts have investigated the relation between corporate social responsibility and consumer behavior. Although many of scholars agree that organizations should accomplish, endorse and publicized corporate social responsibility due to their positive effect on consumer behavior (Maignan, 2001). Contradictory results were found about impact of corporate social responsibility on consumer intentions(Ali et al., 2010). A research conducted by Sen and Bhattacharya (2001) on consumer reaction revealed that corporate social responsibility directly affect consumer's buying behavior. Many other studies have found that there is a 
positive relation between organization's CSR activities and consumer's buying intentions (Ellen, Webb, \& Mohr, 2000; Creyer \& Ross, 1997; Brown \& Dacin, 1997). Mohr, Webb and Harris (2001) found that there is a significant relation between corporate social responsibility and consumer responses. According to Creyer and Ross (1997), consumers consider ethical behavior as significant concern while formulating their decision to buy any product or service from an organization. A study conducted in France and Germany by Maignan (2001); found that consumer regards legal responsibilities as most significant, tailed by ethical than philanthropic and at last economic responsibilities. A research conducted by Visser (2005) in Africa, found that the Carroll Classical pyramid is different from African Pyramid, Economic responsibility was the utmost priority here as well. But the second responsibility favored was philanthropic, tailed by legal and at the last ethical responsibility.

\section{Research Design}

Huck and Cormier (1996) and Pallant (2001) suggest that for a set of items that is to be accepted as having satisfactory internal consistency reliability, the Cronbach's Alpha should be greater than 0.7.The Cronbach's Alpha for one dependent variable and four independent variables is 0.788 which is greater than 0.7.Corporate Social Responsibility and consumer behavior questionnaire was originally developed in English and then translated to Urdu Language and translated back in English to have accurate translation for the study. The translation was done by Urdu PhD student; well versed with the terms used in the field of management. The Questionnaires were personally administrated and distributed in October 2012 in Punjab, Islamabad, Sindh and Khyber Pakhtoonkhwa. A total of 500 Questionnaires were distributed among the consumers of all groups using non probability, convenience sampling to collect the data and by using Google questionnaire. The Google questionnaire link was sent to respondents using Email. Three hundred and thirty responses were received in November, 2012 representing a response rate of $66 \%$. Out of these 330,17 questionnaires were incomplete and only 313 fully completed questionnaires were used for data analysis. SPSS 20.0 was used for analysis of data.

\section{Result and Analysis}

Table 1: Demographics

\begin{tabular}{lll}
\hline Age & Frequency & \multicolumn{1}{c}{ Percent } \\
\hline Age & Frequency & Percent \\
$16-25$ & 71 & 22.7 \\
$25-35$ & 201 & 64.2 \\
$35+$ & 41 & 13.1 \\
Total & 313 & 100 \\
Gender & Frequency & Percent \\
Female & 77 & 24.6 \\
Male & 236 & 75.4 \\
Total & 313 & 100.0 \\
Geographical Location & Frequency & Percent \\
Islamabad & 65 & 20.8 \\
KPK & 57 & 18.2 \\
Punjab & 107 & 34.2 \\
Sindh (Karachi) & 84 & 26.8 \\
Total & 313 & 100.0 \\
Education Level & Frequency & Percent \\
Matric & 47 & 15.0 \\
FSC & 31 & 9.9 \\
Bachelors & 143 & 45.6 \\
masters & 58 & 18.5 \\
MS & 34 & 10.8 \\
Total & 313 & 100.0 \\
Status & Frequency & Percent \\
Married & 117 & 37.4 \\
Single & 196 & 62.6 \\
Total & 313 & 100.0 \\
\hline
\end{tabular}


Table 1 , shows that $75.4 \%$ of the respondents were male and $77(24.6 \%)$ of the Respondents were females. Most of the respondents fall within the age group of 26-35 (64.2\%), followed by age group of 16$25(22.7 \%)$ and $13.1 \%$ of the respondents lies in age group 35+. A total of $107(34.2 \%)$ of the respondents were from Punjab, 84(26.8\%) from Sindh (Karachi), 65(20.8\%) from Islamabad and 57(18.2\%) of the respondents were from Khyber Pakhtunkhwa. A total of 117 (37.4\%) of the respondents were married and 196(62.6\%) of the respondents were single. Total of $143(45.6 \%)$ of the respondents had a qualification level of Bachelors, 58 (18.5) \% Masters, 47 (15\%) Matric, 34 (10.8\%) MS and 31 (9.9\%) Intermediate.

Table 2: Consumer Awareness about Corporate Social responsibility

\begin{tabular}{ll}
\hline Understanding of Corporate Social Responsibility & \% \\
\hline Completely understood & $19.5 \%$ \\
Moderately understood & $48.2 \%$ \\
Little Knowledge of CSR & $31.0 \%$ \\
CSR Definition & Frequency \\
Follow the Law and regulations. & 147 \\
Donate to charitable groups & 255 \\
Maximizing shareholders' value & 109 \\
Contributing in community services & 227 \\
Upholding human rights and minimizing discrimination & 103 \\
Organization should be involved in which of the following CSR activities. & Frequency \\
Community work & 265 \\
Donation & 255 \\
Education sponsorship & 204 \\
Environmental protection & 140 \\
Maximizing shareholders' value & 110 \\
Sport sponsorship & 151 \\
Wildlife protection & 90 \\
Produce safe products & 122 \\
\hline
\end{tabular}

Table 2, shows consumer general awareness towards CSR. According to the survey, $19.5 \%$ of the respondents understood the concept of CSR adequately, 48.2\% understood CSR moderately, 31\% of the respondents had little understanding of the concept of CSR and $1.6 \%$ of the respondents didn't have any knowledge of CSR and their responses were excluded from analysis. Finding shows that "Donate to Charitable" groups has obtained highest frequency (255 counts), followed by "Contributing in Community Services" (227 counts), followed by "Follow the E" (147 counts), followed by "Upholding Human Rights and Minimizing Discrimination" (103 counts). "Maximizing Shareholder's Value" is second last (109 counts) which shows that organization should look at society first and then maximize their stockholders value.

CSR and Consumer Behavior: Table 3shows regression analysis outcomes, that shows the dependence of Economic, Legal, Ethical, and philanthropic Responsibilities (independent Variables) on Consumer Behavior (Dependent Variable). The R square or the coefficient of determination is a percentage of the total variation in the dependent variable that is described by the variation in the independent variables. The significance of independent variables on dependent variable is shown in the Regression table, as the value of R square (.334) shows the impact of CSR elements on consumer behavior is 33.4\% explained. The value of $\mathrm{R}$ Square shows a weak linear relation between Independent variable (CSR elements) and Dependent variable (Consumer Behavior). The Results shows that apart from CSR elements there are other factor that might have impact on consumer behavior i.e. price, marketing, promotion, product characteristics and availability of substitutes.

The coefficient table further explains the relation between CSR and consumer behavior. For all the elements of CSR the p-value is less than 005 that shows that there is significant relation between CSR elements and consumer behavior. The values of coefficient is .240 (Eco), .140 (Leg), .115(Eth) and .194 (PHI). The value shows high relatedness of two independent variables (economic and philanthropic) with Consumer behavior as compare to other variables. 
Table 3: Regression Analysis

\begin{tabular}{|c|c|c|c|c|c|c|}
\hline Model & $\mathbf{R}$ & R Square & $\begin{array}{l}\text { Adjusted } \\
\text { Square }\end{array}$ & $\begin{array}{l}\text { d. Error of the } \\
\text { timate }\end{array}$ & & \\
\hline 1 & $.578^{\mathrm{a}}$ & .334 & .325 & 0019 & & \\
\hline Coeffici & $n_{t s}{ }^{a}$ & & & & & \\
\hline & Model & Unstanda & dized Coefficients & Standardized & $\mathrm{t}$ & Sig. \\
\hline & & B & Std. Error & Beta & & \\
\hline & (Constant) & 1.017 & .193 & & 5.260 & .000 \\
\hline & ECO & .240 & .054 & .250 & 4.416 & .000 \\
\hline 1 & LEG & .140 & .060 & .133 & 2.335 & .020 \\
\hline & ETH & .115 & .050 & .129 & 2.294 & .022 \\
\hline & PHI & .194 & .044 & .246 & 4.449 & .000 \\
\hline
\end{tabular}

Dependent Variable: $\mathrm{CnBeh}$

Independent Variable: ECO, LEG, ETH, PHI

Table 4: ANOVA ${ }^{\mathrm{a}}$

\begin{tabular}{lllllll}
\hline Model & & \multicolumn{2}{l}{ Sum of Squares df } & Mean Square & F & Sig. \\
\hline \multirow{2}{*}{1} & Regression & 24.718 & 4 & 6.180 & 38.586 & $.000^{\mathrm{b}}$ \\
& Residual & 49.327 & 308 & .160 & & \\
& Total & 74.045 & 312 & & & \\
\hline
\end{tabular}

a. Dependent Variable: CnBeh

b. Independent Variables: PHI, ECO, ETH, LEG

In table 4, the (Sig.) column shows that there is a significant relation between all CSR elements and consumer behavior.

Table 5: Correlations analysis

\begin{tabular}{llllll}
\hline & ECO & LEG & ETH & PHI & CnBeh \\
\hline ECO & 1 & & & & \\
LEG & $.515^{* *}$ & 1 & & & \\
ETH & $.408^{* *}$ & $.410^{* *}$ & 1 & & \\
PHI & $.371^{* *}$ & $.401^{* *}$ & $.479^{* *}$ & 1 & \\
CnBeh & $.462^{* *}$ & $.413^{* *}$ & $.403^{* *}$ & $.454^{* *}$ & 1 \\
& & & & & \\
\hline
\end{tabular}

**. Correlation is significant at the 0.01 level.

Consumer behavior is highly correlated with all CSR elements as Table 5 shows, the value .462, .413, .403, and .454 shows that there is a significant relation between CSR elements and consumer behavior so organization should involve themselves in CSR activities as it changes consumer's buying behavior towards that organization. Based on the results obtained as the Beta value shows that Economic responsibility has the most significant impact on consumer behavior, followed by philanthropic, then legal and at last ethical responsibility. The Pakistani Pyramid of CSR is different from that of Carroll Classical Pyramid. According to Carroll (1979), economic responsibility is the basic responsibility followed by legal, ethical and philanthropic responsibility. Our results seem to be same with that of Mohr, Webb, \&Harris (2001) showing that there is significant relation between CSR and consumer responses. The results are also correlated with that of (Sen \& Bhattacharya, (2001). The findings are also same with Creyer \& Ross (1997) study, which shows that consumers give most consideration to ethical responsibility while making a purchase decision. As the results shows, Pakistani consumer priorities seems to be different from that of other nations. The most preferred responsibility was economic responsibility. It is not surprising that Pakistani Consumer ranked Philanthropic responsibility as the second utmost priority as compare to Carroll's legal responsibility. Consumers want organization to contribute to charity, and spend their employee time, facilities in philanthropic activities. Pakistanis are acknowledged as one of the most substantial country in the world with high potent especially amongst its youth. For instance, the donation rate in the country and contribute to help the sufferers of natural 
disasters around the world has been very promising. In response, it is each time been announced that Pakistanis had helped those in need either they are poor, accident victims, orphaned children and so on. Thus, Pakistani consumers' expectation from business organization to do the same philanthropic efforts is undeniable. It is not shocking that Pakistani consumers places legal and ethical responsibilities at last. As we can see the present fragile security/ethical scenario in Pakistan and excessive cases of lawlessness has developed the common public mindset of not valuing much to legal and ethical responsibilities. Either, its public offices, departments or roads, we are accustomed to witness day to day violation of rules and regulations that slowly and gradually have evolved a common perception in Pakistan that legal-ethical values are outdated orthodox beliefs that cannot serve in modern world. That's the main reason Pakistani consumer regards the ethical and legal responsibility less important than economic and philanthropic responsibility. Though, Pakistani Government is trying hard to enforce the strict law and order but it'll take some time to develop an ideal environment where Pakistani consumer would offer more value to legal and ethical responsibilities.

\section{Conclusion and Implication}

For research workers, this study contributes to understand the basic dynamics of the part of Corporate Social Responsibility in consumer buying behavior. The findings formulated by this research show that there is a significant relation between all CSR elements and consumer behavior. Though, the study is vulnerable to some limitations, the research restricted to only few cities has aroused some concerns as Pakistan is a big country and data from few cities cannot be generalized. With only 313 usable respondents, the study might lack external validity of the results. For future researches, the number of respondents should be increased to increase the validity of the results. Future researches may be conducted on different age, gender, race attitude towards CSR, consumer behavior towards socially irresponsible companies. Research should also be carried out to look into some moderating variables. As far as Organization are concerned, they should note that the result of this research support the literature. It suggests that a viable and recognizable consumer group is present that consider companies CSR activities before arriving at any purchase decision. Managers should note that Pakistan consumers have clearly indicated their priorities and the priorities are different from that of other countries. The information extracted from this study can be used to promote company CSR activities. The organization should form up their CSR events keeping in mind the priorities showed in the result of this research, where the economic responsibility has significant relation with consumer behavior, followed by philanthropic responsibility, legal responsibility and at last ethical responsibility. Organizations that are already promoted as socially responsible must be ready to face all type of criticism if being charged of irresponsible behavior, as we are living in the era of information and technology where a company's repute streams within seconds to masses through electronic media as well social media. On the other hand, organizations that ignore Corporate Social Responsibility may face consumer boycotts or social detachment from public. Furthermore, policymakers might use the results of this research to establish minimum standards for Corporate Social Responsibility obedience by organizations, whether controlled or voluntary. Organization, in turn, could be benefited from the support offered by consumers that will not only increase brand awareness and organization image but will enhance the flux to attract stockholders. These effects will have shot term as well as long term impact on organization's performance.

\section{References}

Ahmad, S. J. (2006). From Principles to Practice: Exploring Corporate Social Responsibility in Pakistan. Journal of Corporate Citizenship, 24, 115-29.

Ali, I., Rehman, K., Yilmaz, A., Nazir, S. \& Ali, J. (2010). Effects of Corporate Social Responsibility on Consumer Retention in Cellular industry of Pakistan. African Journal of Business Management, 4(4), 475-485.

Amaeshi, K., Adi, B., Ogbechie, C. \& Amao, O. (2006). Corporate Social Responsibility (CSR) in Nigeria: Western Mimicry or Indigenous Practices? ICCSR Research Paper Series (Nottingham: ICCSR).

Andreasen, A. \& Drumwright, M. (2001). Alliances and ethics in social marketing. Washington, DC: Georgetown University Press.

Arora, B. \& Puranik, R. (2004). A Review of Corporate Social Responsibility in India. Development, 47(3), 93-100. 
Belal, A. R. (2008). Corporate Social Responsibility Reporting in Developing Countries: The Case of Bangladesh. Aldershot: Ashgate.

Black, L. D. (2001). Towards understanding corporate social responsibility in Australia Paper presented at the Conference on Monash University, Melbourne, Australia, Retrieved 3 December 2012 from http://www.aph.gov.au.

Bowen, H. (1953). Social Responsibility of the Businessman. New York : Harper.

Brown, T. J. \& Dacin, P. A. (1997). The company and the product: Corporate associations and consumer product responses. Journal of Marketing, 61(1), 68-84.

Carroll, A. B. (1979). A three-dimensional conceptual model of corporate performance. Academy of Management Review, 4(4), 497-505.

Carroll, A. B. (1991). The pyramid of corporate social responsibility: toward the moral management of organisational stakeholders [Electronic version]. Business Horizons, July-August, 39-47.

Christensen, J. \& Murphy, R. (2004). The Social Irresponsibility of Corporate Tax Avoidance: Taking CSR to the bottom line. Development, 47(3), 37-44.

Commission of European communities. (2001). Green Paper- Promoting a European Framework for Corporate Social Responsibility,COM (2001) 366 final. Brussels.

Crane, A. \& Matten, D. (2010). Business Ethics: Managing Corporate Citizenship and Sustainability in the Age of Globalization. Oxford University Press.

Creyer, E. H. \& Ross, W. T. (1997). The influence of firm behavior on purchase intention: Do consumers really care about business ethics? Journal of Consumer Marketing, 14(6), 421-432.

Davis, K. (1960). Can Business Afford to Ignore Social Responsibility? California Management Review, 2 , 70-76.

Dusuki, A. W. (2005). Corporate Social Responsibility of Islamic Banks in Malaysia: A Synthesis of Islamic and Stakeholders Perspective. PhD Thesis. Loughborough University, UK.

Ellen, P. S., Webb, D. J. \& Mohr, L. A. (2000). Charitable programs and the retailer: Do they mix? Journal of Retailing, 76(3), 393-406.

Ferrell, O. C. (2004). Business ethics and customer stakeholders. The Academy of Management Executive, 18(2), 126-129.

Flack, O. \& Heblich, S. (2007). Corporate Social Responsibility: Doing Well by Doing Good. Business Horizons, 50, 247-254.

Fombrun, C. J., Gardberg, N. A. \& Barnett, M. L. (2000). Opportunity platforms and safety nets: Corporate citizenship and reputational risk. Business and Society Review, 105, 85-106.

Frederick, W. C. (1960). The Growing Concern over Business Responsibility. California Management Review, 2, 54-61.

Freeman, R. E. (1984). Strategic Management: A Stakeholder Approach. Boston: Pitman.

Garriga, E. \& Melé, D. (2004). Corporate Social Responsibility Theories Mapping the Territory. Journal of Business Ethics, 53(1/2), 51-71.

Goddard, T. (2005). Corporate citizenship: Creating social capacity in developing countries. Development in Practice, 15, 433-438.

Harrison, J. S. \& Freeman, R. E. (1999). Stakeholders, social responsibility, and performance: empirical evidence and theoretical perspectives. The Academy of Management Journal, 42(5), 479-485.

Huck, S. \& Cormier, W. (1996). Readin statistics and Research. Harper Collins Publishers Inc.

Lafferty, B., Barbara, A. \& Ronald, E. G. (1999). Corporate credibility's role in consumers' attitudes and purchase intentions when a high versus a low credibility endorser is used in the ad. Journal of Business Research, 44(2), 45-72.

Maignan, I. (2001). Consumers Perceptions of Corporate Social Responsibilities: A Cross-Cultural Comparison. Journal of Business Ethics, 30(10), 57-72.

Maignan, I. \& Farrell, O. C. (2004). Corporate social responsibility and marketing: An integrative framework. Journal of the Academy of Marketing Science, 32(1), 3-19.

Masaka, D. (2008). Why enforcing corporate social responsibility (CSR) is morally questionable. Journal of Business Ethics and Organization Studies, 13(1), 13-21.

Mohr, L. A., Webb, D. J. \& Harris, K. E. (2001). Do consumers expect companies to be socially responsible? The impact of corporate social responsibility on buying behavior. The Journal of Consumer Affairs, 35(1), 45-72.

Mitchell, R. K., Agle, B. R. \& Wood, D. J. (1997). Toward a Theory of StakeholderIdentification andSalience: Defining the Principle of Who and What Really Counts. Academy of Management Review, 22, 853886. 
Pallant, J. (2001). SPSS Survival Manual: A Step by Step to Data Analysis Using SPSS for Windows. Buckingham: Open University Press.

Rahim, R. A., Jalaludin, F. W. \& Tajuddin, K. (2011). The importance of Corporate Social responsibility on conusmer behavior in Malaysia. Asian Academy of Management Journal, 16(1), 119-139.

Roberts, R. W. (1992). Determinant of Corporate Social Responsibility Disclosure: AnApplication of Stakeholder Theory. Accounting Organizations and Society, 17(6), 595-612.

Saleh, M. (2009). Corporate social responsibility disclosure in an emerging market: A longitudinal analysis approach. International Business Research, 2(1), 131-141.

Sen, S. \& Bhattacharya, C. B. (2001). Does doing good always lead to doing better? Consumer reactions to corporate social responsibility. Journal of Marketing Research, 38, 225-243.

Solomon, R. C. (1994). The New World of Business: Ethics and Free Enterprise in the Global 1990s. Lanham, MD: Rowman \& Littlefield Publishers Inc.

Visser, W. (2005). Revisiting Carroll's CSR pyramid: An African perspective. In M. Huniche \& E. R. Pedersen (Eds.). Corporate citizenship in developing countries: New partnership perspectives, (pp. 29-56). Copenhagen: Copenhagen Business School Press.

Walton, C. C. (1967). Corporate Social Responsibilities. California: Wadsworth.

Windsor, D. (2001). The Future of Corporate Social Responsibility. International Journal of Organizational Analysis, 9(3), 225 - 256. 